Please do not remove this page

RMIT

UNIVERSITY

\title{
Truth and politics: Thinking about evidence-based policy in the age of spin'
}

Watts, Robert

https://researchrepository.rmit.edu.au/esploro/outputs/9921860008101341/filesAndLinks?institution=61RMIT_INST\&index=null

Watts, R. (2014). Truth and politics: Thinking about evidence-based policy in the age of spin'. Australian Journal of Public Administration, 73(1), 34-46. https://doi.org/10.1111/1467-8500.12061

Document Version: Accepted Manuscript

Published Version: https://doi.org/10.1111/1467-8500.12061

Repository homepage: https://researchrepository.rmit.edu.au

(C) 2014 National Council of the Institute of Public Administration Australia

Downloaded On 2023/04/26 20:35:21 +1000

Please do not remove this page 
Thank you for downloading this document from the RMIT Research Repository.

The RMIT Research Repository is an open access database showcasing the research outputs of RMIT University researchers.

RMIT Research Repository: http://researchbank.rmit.edu.au/

\section{Citation:}

Watts, R 2014, 'Truth and politics: thinking about evidence-based policy in the age of spin', Australian Journal of Public Administration, vol. 73, no. 1, pp. 34-46.

See this record in the RMIT Research Repository at:

https://researchbank.rmit.edu.au/view/rmit:24574

Version: Accepted Manuscript

\section{Copyright Statement:}

(c) 2014 National Council of the Institute of Public Administration Australia

Link to Published Version:

http://dx.doi.org/10.1111/1467-8500.12061 


\section{EVIDENCE-BASED POLICY IN THE AGE OF SPIN: WHAT DOES THE EVIDENCE SAY?}

History is Philosophy teaching by examples.

Thucydides:

Rob Watts

RMIT University

The current enthusiasm for evidence-based policy in various policy communities is now overwhelmingly well-attested. There is at least one academic journal (Evidence and Policy) devoted to promoting evidence-based policy. Major think-tanks like the Coalition for Evidence Based-Policy in the US, the Centre for Evidence-Based Policy and Practice and the Campbell Collaboration, both in the UK, and agencies like Australia's Productivity Commission (2009) and its indefatigable Chairman, Gary Banks (2009; 2010) have endorsed evidence-based policy strongly. The point of the idea is epitomised by the Campbell Collaboration, (a sibling organization of the Cochrane Collaboration famous for its promotion of evidence based medicine), which conducts systematic reviews 'of the best evidence on the effects of social and educational policies and practices' (The Campbell Collaboration 2003). In the United States, the US Coalition for Evidence Based Policy claims to 'promote government policymaking based on rigorous evidence of program effectiveness'. The sorts of 'rigorous evidence' the Coalition include 'randomised controls' to ascertain effectiveness based on evidence-based approaches that 'have produced extraordinary advances in human health'. The US Coalition suggests that 'in social and economic programs, by contrast, government programs are often implemented with little regard to evidence, wasting billions of dollars and failing to address critical needs of our society' (US Coalition for Evidence Based Policy 2002).

The ever-increasing volume and the sheer bulk of evidence-based policy literature suggests it is an idea whose time has arrived. Systematic surveys like Davies, Nutley and Smith (2000), Oakley (2000) or O'Dwyer (2004) have largely endorsed the idea. O'Donnell (2004) surveyed some 72 major articles, while the Productivity Commission (2009) has cited hundreds of papers and reports: see also Parsons 2002; Nutley 2003; Martens \& Roos 2005; Evans 2007; Pielke 2007; Glasby et al 2007; Cartwright 2009; Argyrous 2009).

Advocates for evidence-based policy conventionally trace its contemporary origins back to exhortations by Britain's Blair government that policy should be guided by evidence in both the 'discovery' of problems meriting policy responses and/or in the evaluation of the effectiveness of 
existing policies and programs (Blair 1997; Cabinet Office 1999a; Cabinet Office 1999b). As Britain's Cabinet Office (1999a: 31) put it, neither 'opinion' nor 'ideology' should make policy. Instead:

... policy decisions should be based on sound evidence. The raw ingredient of evidence is information. Good quality policy making depends on high quality information, derived from a variety of sources - expert knowledge; existing domestic and international research; existing statistics; stakeholder consultation; evaluation of previous policies ... (Cabinet Office 1999a: 31).

They will also note that evidence-based policy was soon picked up by policy communities in Canada, New Zealand and Australia. Canada, eg., which claimed it was taking a leaf out of New Zealand's book, adopted the Canada Performance 2002 project designed to make 'public, on an annual basis, data on indicators that reflect Canada's economic and social objectives' (Zussman 2003: 6). This project required every Canadian department or agency to identify specific outcomes and indicators by which its performance would be judged. As Zussman (2003:7) noted 'the Canada Performance 2002 project ... aims to create an evidential base for the country's performance as a whole, and make it public ...' (See also Davies 2012).

In Australia, as O'Dwyer (2004:10) noted, academics and policy-makers were inspired by the Blair government to support 'evidence-based policy making'. As a new Labour leader tracking behind Blair's Third Way, Mark Latham (2001) took poll position in 2001 when he began talking up the value of evidence-based policy as part of his promotion of 'welfare reform':

The myths of the welfare state are based on old ideological ways of thinking, a struggle between government-first and market-first policies. It is now clear that both approaches are flawed. The world has moved on. Welfare policymakers need to look beyond the old Left and the new Right to those evidence-based policies that can end the human tragedy of poverty.

For Latham, evidence-based policy represented a basis for going beyond 'political ideology'. Latham treated evidence-based policy as part of a 'neutral' technology which would allow 'hard facts' to speak for themselves. Seven years later his successor Kevin Rudd (Rudd 2008), speaking as a new Prime Minister, put his imprimatur on the idea:

Policy design and policy evaluation should be driven by analysis of all the available options, and not by ideology. When preparing policy advice for the Government, I expect departments to review relevant developments among State and Territory governments and comparable nations overseas ... We're interested in facts, not fads. ... Policy innovation and evidence-based policy making is at the heart of being a reformist government.

Yet the contemporary enthusiasm for evidence-based policy at the least is surely puzzling, at the worst as symptom of what Tallis (2011:7) has called 'a tide of CMTP (or 'colonic material of a taurine provenance', a widespread contemporary phenomenon dissected elegantly by the great American philosopher Harry Frankfurt (2005). For those committed to rationality and to the continued salience 
of virtues like truth and 'practical wisdom' (Sharpe and Schwartz 2010), especially in the public sphere and in policy studies, need to insist that even ostensibly commonsense ideas like evidencebased policy need to be subjected to thoughtful appraisal.

In this paper I address several questions. Firstly how credible is the conception of 'evidence' as an objective counter to 'ideological' knowledge or 'opinion' espoused by advocates of evidence-based policy? Secondly what sense is to be made of the coincidence of evidence-based policy and the politics of spin? Finally what sense is to be made of the idea that policy be based on sound scientific evidence when the problem of 'wicked problems' has been repressed by its advocates?

The value of a higher standard of tough rationality than is on display in so much of the evidencebased policy literature implied by the asking of these questions, is initially suggested by the degree of muddle on display in that literature.

\section{The coherence of the advocacy for evidence-based policy?}

Anyone surveying the evidence-based policy literature will almost certainly notice the semantic and conceptual muddle that characterises the field. It is not clear eg., whether 'descriptions' of evidencebased policy are literally descriptive or else normative, or exhortatory. The author/s of Wikipedia displaying the confidence which anonymity confers, proclaim that 'evidence-based policy is public policy informed by rigorously established objective evidence. It is an extension of evidence-based medicine' (Wikipedia 2012). The same confidence, albeit one shot through with contradictions, is evident when O’Dwyer (2004: i) says:

Evidence-based policy is based on research that has undergone some form of quality assurance and scrutiny. This distinguishes it from public policy based on more conventional policy development processes where intuitive appeal, tradition, politics or the extension of existing practice may set the policy agenda.

She then goes on to claim that evidence-based policy will actually be found in what she calls:

... stable policy fields (areas where knowledge is reasonably well settled, theoretical foundations are strong, governments broadly know what works, there is a strong evidence based and incremental knowledge) (O'Dwyer 2004: ii)

It is odd however that O'Dwyer nowhere provides us with even one example where these conditions are met: it is to be seriously doubted whether these conditions obtain anywhere. Yet pages later, when acknowledging the tendency of its advocates to make 'airy 'motherhood statements about evidence-based policy', O'Dwyer allows that one problem is that 'there is actually no evidence (with the exception of health)' that evidence-based policy is actually better than non evidence-based policy (O’Dywer 2004: 12). 
Several other considerations indicate why we need to be both sharper and more thoughtful than seems to be the norm in this particular discursive field.

\section{The objectivity of the 'evidence' in evidence-based policy?}

We might ask eg., what are we to make of the suggestion that there is a far older provenance for evidence-based policy than the Blair government. As Davis, Nutley and Smith (2000:25) note, the normative idea that 'policy be informed by knowledge, truth, reason and facts' characterises governments in the modern era and well before the Blair government. Those making this case will point to disposition the Royal Commission on the Poor Laws of 1832 which employed political economists like Nassau Senior and Edwin Chadwick to construct early versions of the social survey or drew on the testimony of 'expert' witnesses. It is certainly reasonable to allow that even the most cursory survey of the evolution of policy-making in Anglo-American countries over the past two centuries will show that governments frequently claim to have drawn on rational, formal processes of research and systematic inquiry carried out by committees of inquiry or relying on evidence gathered by expert and increasingly academic communities. (See from a vast literature on this matter, Furner and Supple 1990; Brooks and Gagnon, 1994; O'Connor 2001; see too Oakley (2000) on American policy-making in the Progressivist program of reform after 1900). Yet surely this is question begging on a grand scale.

Leaving aside -if only briefly- the question of what might be meant by 'evidence' (see Glasby et al 2007), claiming that policy-making has long been oriented to 'knowledge, truth, reason and facts' is one thing: establishing what any of this means and how credible it is, is an entirely separate matter.

It is perhaps not odd eg., that proponents of evidence-based policy so readily assume the mantle of the Enlightenment ethos and its progressive telos when they claim to see in evidence-based policy a commitment to 'Enlightenment values' like rationality and the use of science. Head (2008:1-2) treats evidence-based policy as the latest manifestation of the 'modern emphasis on rational problem solving, with its modern focus on accurate diagnosis and knowledge of causal linkages'. ${ }^{1}$ He points to the alliance between progressive political impulses and systematic knowledge:

... reaching back to the late Enlightenment, whose leading thinkers sought to undermine the traditional capacity of governments to rely on appeals to precedent, authority and religious values' (Head 2008:9).

Wells (2004:1) says flatly that, 'The notion that policy-making should be 'evidence-based' rather than based on unsupported opinion is difficult to refute'. De Leon and Weible (2010) and Young (2011) eg.,

\footnotetext{
${ }^{1}$ Head (2009:13) it should be noted immediately, remains sceptical, calling evidence-based policy 'an aspiration rather than an accomplished outcome'.
} 
recall Lasswell's (1951) classic argument about the 'well-organised policy cycle' as the bridge between the democratic project and rational knowledge. Almost certainly they have in mind the caricature offered up by Harvey (1989:27) when he claimed that those who made the Enlightenment believed:

That there was only one possible answer to any question. From this it followed that the world could be controlled and rationally if we could only picture and represent it rightly. But this presumed that there existed a single correct mode of representation which, if we could uncover it (and this was what the scientific and mathematical endeavours [of the 'scientific revolution'] were all about), would provide the means to Enlightenment ends. ${ }^{2}$

For evidence-based policy enthusiasts all this has the status of a self-evident truth.

Many of those espousing the virtues of 'evidence-based medicine' and 'evidence-based policy' appear to orient towards a broad-church positivism. Practitioners of evidence-based medicine (EBM) like the Cochrane collaboration have made the randomised, controlled double-blind clinical trial (which compares treatments with placebos to determine the most effective therapeutic intervention) the 'golden standard' of evidence gathering in medicine (The Cochrane Collaboration 2003). Trinder (2000) reminds us that evidence-based policy also shares the long-standing positivist predilection for the 'discovery' of 'objective' facts and evidence, making it possible to exclude the bias imparted variously by 'ideology', 'interests' or 'the passions' (Hirschmann 1997) through standardized scientific procedures and methods.

That said, Trinder slightly overstates the case. Some advocates for evidence-based policy, eg., allow for the admission of 'qualitative data' alongside quantitative data. The ABS (2010: 2) is exemplary in this regard when this agency insists that, 'the use of statistical evidence is vital for making evidence based decisions that guide the implementation of new policy, monitor existing policy and evaluate the effectiveness of policy decisions':. It leavens the positivist cast of its approach when it devotes one paragraph to a description of 'qualitative data' (ABS 2010:9). However it has already preemptively determined that 'statistics are a vital source of evidence as they provide us with clear, objective, numerical data' (ABS 2010: 3). Head (2008) makes a different point when he insists that the dominant 'rational' (ie., positivist) approach to evidence needs to be expanded to include 'inherently political and value-based' knowledge. He insist that 'policy decisions are not deduced primarily from facts and empirical models but from politics, judgement and debates. Policy domains are inherently marked by the interplay of facts, norms and desired actions'(Head 2008:9). In this way Head (2008) gently reminds us of what has been forgotten.

\footnotetext{
${ }^{2}$ For studies that make it impossible to continue to perpetuate this myth, see Israel, J., 2002 Radical Enlightenment, Philosophy and the Making of Modernity 1650-1750, Oxford University Press, Oxford and Holmes, R., 2011, The Age of Wonder: How the Romantic generation discovered the Terror and Beauty of Science, Pantheon, New York. See too what Deutsch (2012:38) has recently called one of the defining aspects of the Enlightenment ethos, its 'affirmative skepticism'.
} 
Many of the advocates for evidence-based policy have forgotten that if 'scientific method' was a central aspect of the Enlightenment conception of 'rationality', so too was the practice of critique and refutation, or what Deutsch (2012) calls 'affirmative skepticism'.

That tradition of 'affirmative skepticism' informs the development of post-positivist philosophy of science initiated by Karl Popper (2002: see also Quine, 1975; Bloor 1991; Hacking 2004). As many writers have noticed, the advocates for the application of 'scientific method', especially to the social world tended to privilege a naïve idea of facts as 'out there' waiting to be 'discovered'. Danziger calls this framework the 'Sleeping Beauty' model (1990: 2) where the facts are awakened by the touch of the scientist-as-prince. Popper's central insight was that the 'facts' neither exist independently of us or outside of the theoretical or constitutive frameworks that make them possible or bring them into existence. In effect all facts are already dependent on us believing certain larger theoretical frameworks to be true: facts are already theory-laden. (Putnam (2005) has made the same point about the interconnectedness of 'fact-value' propositions which subverts the Humean case for maintaining a strict dichotomy between 'facts' and 'values'). As Popper (2002) argued, all of the 'hard' sciences work with constructive schemes which mandate and regulate certain assumptions and practices about what is to count as 'evidence' and as 'real' as well as what practices (like measurement, replicability, or experimental procedure) will permit the generation of explanatory, predictive statements long held to be the technical hallmarks of 'scientific method'. Holton (1984) documented the role played by 'themata' especially in such physical sciences as physics.

This point about theory-laden facts is easily grasped with reference to the Victorian revolution in government of the early nineteenth century. Writers like Dean (1990) have shown that the volumes of 'evidence' collected in the famous Blue Books, was discursively constituted by the advocates of nineteenth century liberal governmentality and the 'themata' like 'individual responsibility', 'philanthropy' and ideas about 'poverty' and 'pauperism'. Here although reliant on a Foucauldian vocabulary of inquiry, Dean is simply making the point made by post-positivist philosophers of science that 'facts-and-theories' and 'facts-and-values' form an effective unity which are really only amenable only to analytic separation. A little etymology here is useful: our word 'fact' comes from the Latin fascere which means 'to make' or 'to do', hence 'factory' a place where things are made, or 'factor', the old term for a servant. A fact refers both things made up or to the deeds or events which about which we might draw legal or other conclusions.

In effect, thinking about the idea that 'policy be informed by knowledge, truth, reason and facts', necessarily raises fundamental problems which cannot simply be swept under the rug by people who insist on the centrality of 'facts' uncontaminated by values or theories. Those problems are best understood by what Hacking (2004) calls 'historical ontology'. Like Foucault (1991), and Kosseleck (2002), Hacking understands that all human modes and styles of cognition requires the construction 
and use of 'categories' and conceptual schemes, and that the construction and use of categories have a history. Accordingly we need to address the interplay between categories (like the 'evidence' category itself, to say nothing of categories designed historically to nominate forms of social action or social relationships, like 'crime', 'unemployment' or 'poverty' and so forth), the empirically verifiable 'stuff' of reality, and the scientific practices of observers and socials scientists. In short the claim that policy has long been 'informed by knowledge, truth, reason and facts' cannot be treated as a selfexplanatory statement so much as a provocation to establish in what ways we can agree that the historical or the contemporary collection of evidence/data or its testing, was, or is actually 'truthful', 'rational' or 'factual'.

Worse as any number of major policy scholars have demonstrated, the naivete of 'evidence-based policy' advocates talking about 'objective facts' is as nothing compared to when Reid (2003) points to an 'inconvenient truth'. Reid (2003:20) notes her surprise at:

...the lack of evidence for evidence-based policymaking either as a process which can take place, or as a process which will lead to better policy outcomes. It might be argued that, far from being unideological, evidence-based policy is, in itself a kind of ideology, and one for which there is remarkably little supporting evidence.

This failure is not a recent failure. It is a sobering, no-less inconvenient truth, that the dominant neo-positivist paradigm on offer in the social and policy sciences, in spite of heroic recent advocacy by the likes of Elster (2007) has simply failed either to develop a 'useable body of predictive generalisations' or 'supply effective solutions to social problems' (Fischer 1998:10: see also Lindblom 1990; Bevir and Rhodes 2003; Head 2008). It would require a considerable diversion to make this large point here so Lemert (1995) or Bishop (2007) must carry the weight of this argument.

\section{Evidence-based policy in the Age of Spin?}

A more interesting and substantial problem is posed by the juxtaposition of the enthusiasm for evidence-based policy with the extent to which modern politics and policy making is now inseparable from 'spin'.

A literature far larger than that which acknowledges the esteem in which evidence is now held, attests to the power of what we now call 'spin' but which in earlier, plainer times we called 'propaganda'. The larger significance of this for our understanding of contemporary democracy has been spelled out by Wolin (2008) and his account of 'inverted totalitarianism'. ${ }^{3}$ Wolin belongs to a

\footnotetext{
${ }^{3}$ Wolin's treatment is far removed from the older literature on the links between totalitarianism and propaganda. Ellul (1965) mindful of the use of modern media made by totalitarian states in the 1930s, insisted eg., on the totalising reach of propaganda which:

... reaches individuals enclosed in the mass and as participants in that mass, yet it also aims at a crowd, but only as a body composed of individuals. Propaganda must be total. The
} 
classic tradition of inquiry constituted by Arendt (1958; 1967), Ellul (1973), Hermann and Chomsky (1988) and Habermas (1989). It is a tradition which worries about the effects for democratic politics of the increasingly managed flow of political opinion and information in whatever passes now for the 'public sphere'(eg., Calhoun 1992; Dahlgren, 2005). Wolin implies that the US is the only nation-state to manifest the key features of what he calls 'inverted totalitarianism' and 'managed democracy'. It is hard however not to see in his account more than a passing reference to the contemporary political culture of Australia or the UK.

Wolin insists that three key feature distinguish contemporary 'inverted totalitarianism' from earlier state-centric models of 'totalitarianism' found in Italy, Germany or the former USSR in the 1930s and 1940 's. In formal terms those features include the key difference that while the state dominated the market in the totalitarian models of the 1930s, under inverted totalitarianism business interests use contributions, public relations and lobbying to ensure that the government acts to promote the interests of large corporations, and 'the market' more generally. This is considered 'normal' rather than corruption (Wolin 2008: 51). Secondly and again unlike the original totalitarian forms which sought to mobilise the people continuously or to elicit their will through plebiscites, managed democracies seem to prefer to keep the mass of the population in a persistent state of political apathy. The only type of political activity expected or desired from the people is voting. Low electoral turnouts in England or the USA are treated as evidence that everyone accepts the situation rather than treating it an indication that the bulk of the population has given up expecting that the government will ever help them (Wolin 2008: 64). Finally while the totalitarian states openly ridiculed the democracies of the 1930s, modern managed democracies claim that democracy is the only political form to have proved its legitimacy (Wolin 2008: 52). sx Indeed so convinced of this are some managed democracies that democracy warrants being exported courtesy of militarily imposed regime change or via the aggressive promotion of a human rights agenda -even though their own record less than squeaky clean on this score (see Ignatieff 2005).

That Wolin's is a normative conception of politics is clearly suggested when he writes:

It is all politics all of the time but a politics largely untempered by the political. Party squabbles are occasionally on public display, and there is a frantic and continuous politics among factions of the party, interest groups, competing corporate powers, and rival media concerns. And there is, of course, the culminating moment of national elections when the attention of the nation is required to make a choice of personalities rather than a choice between alternatives.

propagandist must utilize all the technical means at his disposal- the press, radio Propaganda tries to surround man by all possible routes, in the realm of feelings as well as ideas, by playing on his will or on his needs, through his conscious and his unconscious, assailing him in both his private and his public-life. It furnishes him with a complete system for explaining the world, and provides immediate incentives to action. 
What is absent is the political, the commitment to finding where the common good lies amidst the welter of well-financed, highly organized, single-minded interests rabidly seeking governmental favors and overwhelming the practices of representative government and public administration by a sea of cash (Wolin 2008: 66).

Wolin's part in a tradition marked by concern for the effect on politics of managing the flow of opinion and knowledge is clear. Wolin understands the point made by so-called father of propaganda (aka 'public relations') by Bernays (1928: 37), even if he does not accept Bernay's functionalism, or his apologia for propaganda:

The conscious and intelligent manipulation of the organized habits and opinions of the masses is an important element in democratic society. Those who manipulate this unseen mechanism of society constitute an invisible government which is the true ruling power of our country ... We are governed, our minds are molded, our tastes formed, our ideas suggested, largely by men we have never heard of. This is a logical result of the way in which our democratic society is organized. Vast numbers of human beings must cooperate in this manner if they are to live together as a smoothly functioning society.

The contemporary repression of the term 'propaganda' and the preference for talking instead about 'spin' itself speaks volumes. It is characteristic eg., that writing about the Australian case, Ward (2003:25) has suggested we should now be taking the idea that we have a 'public relations state' seriously, if only because the 'broad contours of the Australian PR state seem clear enough' by which Ward means 'a whole-of-government integration of information disclosure activities'. The more serious albeit ironic point to be made is that if the Blair government is associated with the rise of evidence-based policy it is his government which also sponsored a revival of interest in spin. So along with a vast literature on evidence-based policy we also have an ever-ramifying literature documenting the evolution of modern 'spin' and its effects (eg., Kurz 1998; Jones 1997; Cappella and Jamieson 1997; Franklin 1994; Garnham 1992; Beresford 1998; Harris 1999; Harris Moss and Vetter 1999; Harris and Wring 2002; Partington 2003; van Onselen \& Errington, 2005, Stockwell 2007; Jones 2007; Pearson and Mclean 2010). Equally and perhaps as might have been expected, the juxtaposition of the Blair government's enthusiasm for evidence-based policy with its enthusiastic use of spin seems to have largely gone unremarked. This probably reflects the refusal to contemplate what is actually at stake.

What is at stake is suggested by the paradigm case of the evidence collected in favour of the invasion of Iraq by allied nations led by the US in 2003. As is now well established, the governments of the United States, the United Kingdom and Australia mobilized popular support for, and then legitimized their invasion of Iraq by claiming that the Hussein regime possessed weapons of mass destruction 
(WMD). ${ }^{4}$ In each case the respective governments mounted an unstinting and costly effort to successfully mobilize public (ie., media) opinion in favour of an invasion. These regimes claimed that their intelligence agencies had evidence contained in dossiers pointing to the existence of WMD. The pursuit of indubitable evidence of those WMD afire the invasion of Iraq began proved to be a difficult task. This was not surprising given the fact that there were no WMD. Spin proved decisively more influential than any evidence.

That said, the contemporary dominance of spin seems to be defined most commonly in relatively anodyne ways. Grattan (1997:34) eg., speaks simply of 'the highly professional selling of the political message that involves maximum management and manipulation of the media'. Stockwell (2007: 2) implies that 'spin' involves simply:

... the backgrounding and interpretation supplied by media advisers to the press to put

politicians' pronouncements in a favourable context and to ensure that the message that they (the politicians) are trying to get across, actually appears in the media.

However Mayer (1994) put a more provoking view of spin, one which opens up the question of truth and thereby the relationship of spin to evidence-based policy. He did this when he pointedly suggested:

...political advertising is necessarily full of deception, half-truths, exaggerations and falsities. It is that way because all forms of politics are that way, but political lies are not like lies about soap or cornflakes. Politics does not deal with 'products' which can be checked and evaluated in the way a car can be ... If worried enough to care, you can compare brands of way you can compare soft appeals which rely on fantasy, pride, ego-boosting, fear or alienation. (Mayer, 1994: 119)

Mayer goes on to subvert the very conception of truth:

If you found a way to make all political advertising rational and accurate, or even if you improved its rationality and accuracy greatly, what would you have to do? ... You would have to eliminate politics as we know it (Mayer, 1994: 116)

Indeed Mayer proposed a model of political deception in ways that parallel Arendt's (1967) even more ironic treatment of the relationship of truth and politics.

\footnotetext{
${ }^{4}$ The case for invasion rested on the claim that Iraq had missiles, nuclear capability and lots of biological and chemical weaponry. The chief source used by the Bush administration in 2002-3 to justify its claims was a low grade technician, taxi driver and fantasist (Drogin 2007) As late as 2002 investigators with the United Nations Special Commission (UNSCOM) like Scott Ritter were confirming (See Stampton \& Rauber 2003). The claims vigorously promoted by the American and British governments were accepted by the Australian government. We also now know that the US government spent billions of dollars after 1998 hiring leading PR companies like Beers, to promote an increasingly hostile view of Iraq after 1998.
} 
Yet the possibility that modern politics and policy making has less to do with a regard for truth and more with 'spin', points to a number of problems about the interaction between politics and knowledge in which some conception of truth remains as Arendt (2005: 5-8) suggested, a vital issue in the practice of politics and the practice of persuasion.

Arednt adopts the view that politics and what she calls 'factual truth' are antagonistic. Her (1967) discussion of the terms of that antagonism begins with a distinction between 'rational truths' and 'factual truths' even though she really wants to talks about factual truths. 'Rational truths' are the truths given by philosophy, science and mathematics like the proposition that the three angles of a triangle necessarily are always equal to two angles of a square. 'Factual truths' deal with human events and facts about which it is possible to tell lies -and do so successfully. 'Factual truths' are about factual realities which are mutable and can change over time. We can also produce factual truths about opinions, events, and decisions.

While factual truths can be about opinions they are not opinion's. It is a fact eg. that Germany invaded Belgium in 1914 )and not the other way around), or that France collapsed before the German armies in 1940.

Factual truth ... is always related to other people: it concerns events and circumstances in which many are involved; it is established by eyewitnesses and depends upon testimony ... It is political by nature. Facts and opinions thought they must be kept apart, are not antagonistic to each other; they belong to the same realm (Arendt, 1967:300)

Factual truths reflect the messiness of the world. The realm of human affairs is defined by what Kant called the 'melancholy haphazardness' of a sequence of events which makes up the course of the world 'Facts have no conclusive reason for being what they are; they could always have been otherwise and this annoying contingency is literally unlimited'. .

Truths, whether rational or factual, share one trait in that 'they are beyond agreement, dispute, opinion or consent. They are not changed by the numbers or lack of numbers who entertain the same proposition' (Arendt 1967: 302). From the viewpoint of politics, 'factual truths are despotic and uncomfortable and so enjoy a precarious status in the eyes of government that rest on consent and abhor coercion'. Truth is hated by tyrants 'because facts are beyond agreement and consent and all talk about them -all exchanges of opinion based on correct information will contribute nothing to their establishment'. As she says 'unwelcome fact possess an infuriating stubbornness that nothing can overcome except plain lies'. Equally those with power and opinion which finds these facts unpalatable can and will set out to subvert truth; even Jefferson who declared in his draft of the US Declaration of Independence that certain propositions like 'all men are created equal' were selfevident truths, necessarily implied that they were nothing of the sort, but stood in need of 
agreement and consent, both distinctively political attributes: to become politically relevant these truths needed to mutate into opinions so that they could enter the 'political realm'.

'Truth though powerless and always defeated in a head-on clash with the powers that be, possesses a strength of its own: whatever those in power may contrive they are unable to discover or invent a viable substitute for it. Persuasion and violence can destroy truth but they cannot replace it' (Arendt 1967: 309). This is why Arendt suggests that 'The hallmark of factual truth is that its opposite is neither error nor illusion, no one of which reflects upon personal truthfulness, but the deliberate falsehood or lie, Error of course is [also] possible and even common with respect to factual truth ...

Arendt shares with Mayer a darker insight into the increasing reliance on propaganda and deception suchthat the result of a consistent and total sunpbstiution of lies for

truth is in one sense only possible from an outsider's position and so outside the political realm here she speaks of the 'solitude' of the philosopher, the 'isolation' of the artist and scientist, the 'impartiality' of the historian and the judge(1967: 310). Likewise Arendt praises the judiciary and the university as special spaces devoted to truth telling: '... very unwelcome truths have emerged form the universities and very unwelcome judgments have been handed down from the bench from time to time' such that the chances for truth to prevail in public are greatly improved by the existence of such places'.

Does this consideration alone suggest something about the way an idea like 'evidence-based policy' needs to be put in context? I think so hence my intention to critically appraise the idea of evidence-based policy, with a view to establishing if evidence-based policy can live up to its promise as an idea whose time has come (Young et al., 2002). In addressing a few of the questions that matter, I begin by exploring the idea of 'evidence' in evidence-based policy. Finding a coherent account of evidence-based policy is a difficult task. In much of the policy literature the meaning of 'evidence' and 'evidence-based policy' is treated as if it is either self-explanatory or else is collapsed back into one form or other of a narrow band of 'empiricist' or 'quantitative' research methods. As we suggest here far more is at stake than some methodological squabbles. If we take seriously the ideas of putting evidence-based policy back into its context then we cannot help but observe that any discussion of evidence- 
based policy needs to engage the fundamental relation of knowledge and political processes mediated by preferences interests and conceptual schema.

Simply claiming that the past few centuries have actually been characterised by governments making use of 'rational' or 'factual' research based evidence is reckless in a number of ways. One of those ways is that such claims inevitably raises a major problem which should never have been forgotten about, namely why is it that policy-makers continue to face 'wicked problems' (Rittel \& Webber 1973). This problem, which has only occasionally been acknowledged in the Australian policy literature (Australian Public Service Commission 2007; Public Policy Institute 2011), seems nonetheless to have been significantly repressed in quite interesting ways in the recent discussion about evidencebased policy, and along with it the vexed question what 'evidence' will be used to show that 'What counts is what works' (Blair 1997). Head (2009) eg., represses the issue of wicked problems] ie the role played by scientism.

Here I address three questions

1.What conception of evidence is at work in the EBP movement?

2. Why are some problems wicked and why has the problem of wicked problems been repressed by EBP? [Head (2009) eg., represses the issue of wicked problems] ie the role played by scientism ...

3. What light does Arendt shed on the relation of truth to politics in an age of spin?

I begin by considering what conception of evidence appears to lie at the heart of the EBP idea.

Simply claiming that the past few centuries have actually been characterised by governments making use of 'rational' or 'factual' research based evidence is reckless in a number of ways. One of those ways is that such claims inevitably raises a major problem which should never have been forgotten about, namely why is it that policy-makers continue to face 'wicked problems' (Rittel \& Webber 1973). This problem, which has only occasionally been acknowledged in the Australian policy literature (Australian Public Service Commission 2007; Public Policy Institute 2011), seems nonetheless to have been significantly repressed in quite interesting ways in the recent discussion about evidencebased policy, and along with it the vexed question what 'evidence' will be used to show that 'What counts is what works' (Blair 1997). 


\section{THE ORIGINS AND CONTEXT OF EVIDENCE-BASED POLICY}

Those who promote 'evidence-based policy' rely on the credibility accruing from 'evidence-based medicine'. This legacy of ideas even now informs the contemporary enthusiasm for evidence-based policy both overseas and in Australia.

Evidence-based medicine (EBM) is the process of systematically finding, appraising, and using research findings as the basis for clinical decisions. The philosophical underpinnings of evidence-based medicine are clearly those belonging to a broad-church positivism. This is evident eg., in the way the 'golden standard' of evidence gathering in medicine is the randomised controlled trial, which compares treatments with placebos to determine the most effective intervention (The Cochrane Collaboration 2003). The Cochrane Collaboration, first established in the United Kingdom, has been at the forefront of the push for systematic up-to-date reviews of all relevant randomized controlled trials of health care (Trinder \& Reynolds 2000). The results of these systematic reviews are posted electronically on the Cochrane Library to form a searchable database.

The rigorous 'scientific' process of systematically reviewing the effects of health care treatments underpins evidence-based medicine. Widely adopted in the United Kingdom, and increasingly in the United States, evidence-based medicine is used to identify the most appropriate and effective way to promote health and to treat illnesses. In this sense it has both educative and clinical functions (Solesbury 2001). The logic of evidence-based medicine has spread out of acute medicine into allied health professions and then into related areas like social work and human service practice (McDonald 2002).

Yet the take-up of evidence-based medicine has not met with universal approval. Some commentators suggest that evidence-based medicine constrains other forms of scientific research and/or promotes an overly narrow range of research methodologies (Reynolds 2000: 32). These comments are directly relevant to debates about the value of evidencebased policy, as the disciplinary and methodological roots of the 'evidence-based' discourse in acute medicine has implications for how these ideas are transferred to other areas of professional practice, such as policy-making in the human services. 
Researchers and policy-makers in Britain have been driving the evidence-based policy movement, aiming to systematically mobilize and use social science research. The Campbell Collaboration, a sibling organization of the Cochrane Collaboration, focuses on social policy research and aims to conduct systematic reviews 'of the best evidence on the effects of social and educational policies and practices' (The Campbell Collaboration 2003). Beyond making systematic reviews electronically available for policy practitioners, evidence-based policy is also seen by some as a way of bringing social science researchers and their work into closer alignment with government decision-making processes (Parsons 2001).

Not surprisingly, there have been vigorous debates in the UK about the implications of this trend, regarding the appropriate relationship between universities and government decision-makers, intellectual property rights and academic freedom. ${ }^{5}$ The Economic and Social Research Council, the Britain's leading independent agency for funding research and training in the economic and social sciences, has been caught up in these debates. Commenting on these issues, Solesbury (2001: 4) observes that 'the Economic and Social Research Council has been subjected to the demands of government science policy that views academic research as a means to economic and social development, much more than a cultural end in itself'. These efforts have been coordinated by a number of Economic and Social Research Council funding initiatives. In 1999, for example, the ESRC provided 1.3 million pounds to the Evidence Network - the UK Centre for Evidence-Based Policy and Practice for a period of three years:

The primary objectives of the Centre for Evidence-Based Policy and Practice are to foster the exchange of research-based evidence between policy researchers and practitioners, and to accelerate the development of methods of appraising and summarising the results of research relevant to policy and practice. It will also aim to improve the quality of research and practice, and through its dissemination function inform and advise those in policy-making roles (Evidence Network - UK Centre for Evidence Based Policy and Practice, 2002).

\footnotetext{
${ }^{5}$ In Britain both Liberal Democratic politicians and academics have publicly raised concerns about the increasing practice of government departments amending research reports before publication and contractual conditions that insist researchers seek departmental permission before speaking publicly to the media about research findings (British Educational Research Foundation, 2001).
} 
These objectives are similar to the aims and methods of the Cochrane Collaboration and the Campbell Collaboration outlined earlier, where the intention is to systematically review available research for practitioners working in a range of policy settings.

The Cabinet Office Centre for Management and Policy Studies in the United Kingdom (1999a; 1999b; 2001) has produced a number of strategic documents aimed at 'modernising the policy-making process'. Evidence-based policy is seen as a core dimension of this process. In the 1999 British Cabinet Office White Paper on Modernising Government, evidence-based policy is understood as including:

- Reviewing existing research;

- Commissioning new research;

- Consulting relevant experts; and

- Considering a range of properly costed and appraised options.

From the perspective of those advocating for an evidence-based approach, professional policy-making is best driven by 'evidence' of 'what works', following a series of systematic steps (eg., Parsons 2001). In the United States, the US Coalition for Evidence Based Policy aims to 'promote government policy-making based on rigorous evidence of program effectiveness'. The sorts of 'rigorous evidence' the Coalition promotes consist of 'randomised controls' to ascertain effectiveness based on evidence-based approaches that 'have produced extraordinary advances in human health'. The US Coalition suggests that 'in social and economic programs, by contrast, government programs are often implemented with little regard to evidence, wasting billions of dollars and failing to address critical needs of our society' (US Coalition for Evidence Based Policy 2002). In this approach to 'evidence', the term takes on a new meaning as a resource-rationing tool, which goes beyond its educative and clinical purposes outlined earlier.

Underpinning the Cochrane Collaboration and other evidence-based initiatives is the long standing positivist expectation that it is both possible and desirable to exclude bias through standardized, rational and neutral procedures and to generate 'objective' 'rational' and 'truthful' evidence (Trinder 2000). From outside that perspective the emergence of evidence-based policy is bets understood as an offshoot of the instrumentalist mode of managerial 'reforms' that have infiltrated public administration practices in many western 
democracies over the past three decades. Trinder (2000) argues that the managerialist emphasis on 'value for money' and a 'focus on effectiveness and efficiency is a central driving force behind evidence-based practice and policy'. In the case of managerial reforms and evidence-based policy, the technical logic is similarly concerned with procedural competence, rather than substantive output.

\section{Wicked problems}

In particular the question of whether and by what means the advocates of evidencebased policy believe that relying on 'evidence' somehow overcomes certain basic problems in the vexed relationship between politics and truth ought to be a central issue in our time. Certainly one suspicion is that those appealing to evidence based policy are making some claim that policy-making itself is already, or might become a 'science' (Grayson 2007). As Young, et al. (2002: 215) observe this claim may refer somewhat ambiguously either to 'to the way in which policy is made ... [or] to the evidential nature of social science itself'. Either way this proposition has been contested quite sharply by Mulgan (2005: 224) when he suggests that in 'a democracy, the people and the politicians have every right to ignore evidence'.

Our starting point is that whatever the merits of the natural or social sciences we need to accept that most if not all policy-making exercises, as some experienced policy-makers will all too readily acknowledge, are ultimately and necessarily political processes (Rose 1999; Edwards 2000; Bessant et al 2006). This suggests that 
there is more at stake here than a somewhat narrow and typically academic preoccupation with issues of methodology such as occurs when social scientists adjudicate the merits of various styles or research, research methodologies or evaluate 'data'.

After all,

This sheds an interesting light on the political and policy use of evidence, and opens up a series of interesting questions about the character and role of evidence in contemporary policy-making processes more generally. Certainly as writers like Rose (1996) have suggested, the relationship of evidence to fantasy evident in state policy exercises may need to be taken more seriously than simple-minded empiricists seem able or willing to do. Any consideration of the juxtaposition of the enthusiasm for evidence-based policy and the recognition that modern politics has less to do with a regard for truth and more with 'spin' points to a number of problems about the interaction between politics and knowledge in which some conception of truth remains as Arendt (2005: 5-8) suggested, a vital issue in the practice of politics and the practice of persuasion. At stake as we show are serious questions about truth, political judgment and the strange usages to which evidence can be put.

Le us start with the idea of evidence-based policy itself. 
In Australia, it is clear that evidence-based policy has begun to reshape the social and public policy field, especially in the lexicon of policy-makers working in both the community and government sectors. However in contrast to the United Kingdom, there is no formal coalition or central coordinating 'think tank' actively promoting this agenda at a Commonwealth Government or State Government level. Nonetheless, within and across government departments there are signs that evidence-based policy is being actively promoted across a number of different fields of social policy. In 1998, the Commonwealth Department of Health and Family Services was talking about the need to translate evidence-based medicine into evidence-based policy, which is defined in terms of assisting the provision of safe, cost-effective and beneficial treatments (Whitworth, 1998). Again in the health field, the National Health and Medical Research Council (2003) offers Practitioner Fellowships on the basis that they contribute to 'evidence-based policy development in Australian health systems'. It is not really surprising that the health field has been the first to take up the evidence-based discourse, given the proximity of this profession to acute medicine.

There are plenty of signs that evidence-based policy is being taken up in other areas of public administration. The Department of Family and Community Services (DFaCS) 
Annual Report 2000-01 refers to evidence-based policy, by way of 'making administrative data more accessible to the Minister, DFaCS staff and the Australian community' (DFaCS, 2001). In this account, evidence-based policy is defined along the lines of accessible information provision for policy-makers and the general public, echoing the aims of The Campbell Collaboration. In the area of income support, Centrelink's 2002-05 Business Plan makes a case for Centrelink's being 'a key player in developing and delivering evidence-based policy solutions for customers, client agencies, community and government' (Centrelink, 2002). A Commonwealth Department of Education, Training \& Youth Affairs publication on The Impact of Educational Research on school education quotes a senior official, who argues that 'schools will only accept changes that are strongly evidence-based' and that 'research helps to de-politicise educational reform' (DETYA, 2000: 190).

In this context, research evidence is treated as a 'neutral' and 'objective' policy tool that is apparently above political ideology. Increased targeting of social policy programs and the shift towards 'outcomes based funding' in the non-government human services sector also provides fertile ground for evidence-based discourse. Non-government welfare agencies must increasingly quantify what they are doing, what works and why. In the human services, evidence-based policy cannot be separated from a broader political context where eg.,

... efficiency becomes the primary political value, replacing discussions of justice and interest with discussions of what is possible and practical, with means rather than ends, with methods rather than truth' (Smith \& Kulynych 2002: 163). 
Australian research institutes, funded by the Commonwealth Government, have also begun adopting the language of evidence-based policy. The Australian Institute of Family Studies was funded in the 2000-2001 Federal Budget to undertake a Longitudinal Study of Australian Children. According to the first paper on the project: ... the Strategy is based on a holistic approach to problem identification, prevention and early intervention, and a commitment to evidence-based policy and practice' (AIFS 2002).

Winter and Seelig (2001: 6) have promoted the idea of evidence-based policy and research in Australian housing studies as involving the use of 'evidence for policy formation'. Young et al (2002: 216) refer to this conceptualisation of research-policy relations as the knowledge driven model, where it is assumed that knowledge leads, or at least should lead policy.

Actors in the political field have also been drawing on the concept. In Australian federal politics, for example, a variety of leading ALP politicians have espoused the virtues of evidence. Mark Latham (2001) took poll position in 2001 when he began talking up the value of evidence-based policy as part of his promotion of 'welfare reform':

The myths of the welfare state are based on old ideological ways of thinking, a struggle between government-first and market-first policies. It is now clear that both approaches are flawed. The world has moved on. Welfare 
policymakers need to look beyond the old Left and the new Right to those evidence-based policies that can end the human tragedy of poverty.

For Latham evidence-based policy represented a useful tool and theoretical metaphor for going beyond political ideology. Latham treats evidence-based policy as a 'neutral' concept where 'hard facts' will speak for themselves in addressing 'human tragedy' and politicians and policy makers will act accordingly based on the best available evidence.

This brief account of how evidence-based policy has entered the Australian social policy discourse is far from comprehensive. However, it illustrates different manifestations of evidence-based policy and the inroads that it is making into public management and social policy in Australia and other parts of the western world. A simple part of the reason for current interest in evidence-based policy may be explained by the 'common sense' nature of the term. It is difficult to imagine anyone standing up and arguing that policy should not be based on anything but the best available evidence. The idea has an intuitive logic, which helps to explain how the concept is 'naturalized' in a diverse range of policy settings. As Tilley and Laycock (2000: 13) argue: 'rooting policy in evidence has all the appeal of motherhood and apple pie. The rhetoric is cheap and easy'. The term works as a conventional catch phrase synonymous with 'scientific', scholarly' and 'rationality', constituting a rhetorical framework for thinking about modern policy-making and professional human service practice in highly positive ways. 
This is especially apparent in the UK and Australia where evidence-based policy is made part of a 'modernising' agenda where policy-making scholars and practitioners assume the mantle of scholarly, scientific and above or else rational practice. (Where once the science of government was treated as matter for universities to organise (signified for example by the establishment of the LSE in 1909 or Bland's establishment of a School of Government at Sydney University in the 1930s, the modern way involves institutional 'partnerships' between governments and universities like ANZSOG). In this respect, 'the resurgence of evidence-based policymaking might be seen as a re-affirmation of the 'modernist' project, the enduring legacy of the Enlightenment, involving the improvement of the world through the application of reason' (Sanderson, 2002: 1). In sum, the evidence-based policy movement is premised on the simple proposition that scientific research evidence has an inherent value in the everyday politics of policy-making.

However the question whether 'empirical research' actually assures a sufficiently secure grasp of the social world to deliver reliable insights into that world able to inform defensible policies is another, far more serious question. To raise that question leads to other no less interesting questions like how much weight should, or could ever be given to research evidence in policy-making processes. Are not all policy-making exercises as even hardened policy-makers will acknowledge, ultimately and necessarily, a political process? (Rose 1999; Edwards 2000). A second set of questions that also need some elucidation entails asking what kinds of evidence are the promoters of evidence-based policy advocating? Are some kinds of evidence to be privileged over others? Are the current conceptions of 'evidence' eg., 
based on certain narrowly conceived methodologies that privilege certain forms of methods and knowledge over others?

Our interest here is in critically appraising the emergence of evidence-based policy discourse in Australia. While we cannot address all of the questions that matter it is possible to ask whether evidence-based policy can live up to its promise as an idea whose time has come (Young et al., 2002). That the enthusiasm for evidence is both more curious and more paradoxical than might be immediately apparent is suggested by several considerations.

\section{EVIDENCE-BASED POLICY IN AN AGE OF SPIN: THE CASE OF POVERTY AND} WELFARE POLICY

Firstly there is the coincidence of the commitment of governments, including Britain's Blair government and the Howard government, to both evidence-based policy and to the politics of spin. The extent to which this conjunction involves a contradiction or various combinations of hypocrisy or stupidity is a moot question given the primacy now accorded to ceaselessly gathering data about the state of public opinion provided by relentless polling most of it generated by and then reported in the media. Campbell's (2007) insider's account of how the 'politics of spin' worked in Whitehall points to the serious consequences for politics itself. Ballard (2007: 100) eg., is not alone when he observes how modern politics has been reconstituted for the age of cable TV news. The result is a politics reliant on: 
... fleeting impressions, an illusion of meaning floating over a sea of undefined emotions ... a virtual politics unconnected to any reality, one which defines reality as itself [and one in which] the public willingly colludes in its own deception.

Bourdieu (2008: 189) with his characteristic acerbic ability to get to the point characterises modern politics as a process in which politicians:

... enclose themselves ever more in their hermetic pursuit, often with no other communication wit the outside world except polls that produce responses by the very questions they impose, and a number of them, moved solely by a concern to simply exist (like pretenders) or survive (like dethroned champions), mutually determine one another in actions that, far from being based on ethical conviction or devotion to a political cause, are no more than reactions to the reactions of others. The peak of perversion is reached when, with television performance becoming the measure of all things, communication advises guided by opinion pollsters train politicians to mime sincerity and play at conviction.

The consequences for political life of this preoccupation with 'evidence' and the role played by government agencies in developing a 'politics of fear' (Furedi 2006) is suggested when we recall the widespread sense that we now face unique new threats to our security. ${ }^{6}$ The practical consequences of this as Agamben (1999;

\footnotetext{
${ }^{6}$ If public opinion polls are to be believed for example, many Australians believe that the world is not a safe place anymore and we need to defend ourselves from terrorists intent on destroying the Australian way of life' or attacking 'the West'. Many Australians appear to accept that they are engaged in a 'war against terror' waged by 'radical' or 'fundamentalist' Muslims that began with the 9/11 attacks on New York and Washington in 2001. Australia joined with the USA and Britain in a
} 
2004) has argued, include moves by western states to suspend the rule of law and create states of exceptionality (involving the reintroduction of state-sanctioned torture (Danner 2007). The means by which fear is manufactured has been superbly documented by Marr and Wilkinson (2006) in their forensic account of the systematic exercise orchestrated by the Howard government in September 2001 to mislead the Australian people about the rationale for their handling of the request by the MV. Tampa to transfer a number of asylum seekers they had rescued from a sinking boat.

Marr and Wilkinson remind us of what is at stake. In this case the Howard government's use of ostensibly 'objective' images of babies apparently being thrown overboard, help to frame a sharp question or two about the nature of evidence and the capacity of seemingly objective things like photographic images to deceive or mislead. Here Daston's and Gallison's (2008) account of the history of the idea of 'objectivity' and the variety of practices said to generate or guarantee it, points if nothing else to the problematic authority vested in photographic techniques as a guarantee of what they call 'mechanical objectivity').

This line of enquiry insists that we think more and better about the relationship between politics and truth.

'Coalition of the Willing' first in an invasion of Afghanistan in 2002 and then of Iraq in March 2004 apparently to prevent Iraq using its arsenal of 'weapons of mass destruction' against the West. In August 2005 an A.C. Nielsen poll showed that $70 \%$ of Australians expected a terrorist attack in Australia in the 'next few years'. In January 2006 one news poll had 87 percent of those surveyed fearful about terrorism. FOXTEL TV news polls in August 2005 and again at the end of 1007 suggested that more than between 80 percent and 90 percent of Australians were prepared to relinquish most of our civil liberties in order to have stronger security laws. 
If the contemporary 'politics of fear' works by conjuring up 'evidence' of states of affairs that are not quite what they seem, then there are no less interesting questions about how it is possible that robust evidence that something is there is ignored. Our own interest in Australian social policy provides rich material for reflecting on this problem. The salience of this is suggested for example when recalling as has been noted on more than one occasion, how it is possible that a social problem like 'poverty' continues to be 'discovered' or 'rediscovered' from time to time even as relevant evidence is systematically repressed or simply ignored.

The actual regard for evidence and its capacity to function as it is supposed to do, that is as a source of rational persuasion is put into a strange new light when we look at recent policy research that has informed Australian welfare policy development. This case subverts any conventional thinking about the value of evidence. Indeed this case suggests that evidence that contradicts what is already 'known' and widely believed to be the case is strongly to the fore in the sad and sorry history of Australian welfare policy. This seems to have one general aspect and one, more specific feature

On the one hand it seems that generally our policy community has not been all that able or willing to puzzle sufficiently well about the strange capacity to keep on (re)'discovering' 'poverty'. 
The notion of 'rediscovery' certainly overstates both the novelty and the status of these recurrent discoveries. In Australia for example there is a record of persistent research effort undertaken since the mid-1960s into poverty (Encel 1988; 1990; Sitsky 1989). This (re)discovery' raises some basic questions about the social and political significance of income inequality research in contemporary Australian social policy. That there is a point to 'problematising' seemingly 'obvious' processes of discovery such as this, was first raised in Australia by Geoff Sharp. At the height of an earlier 'rediscovery' of poverty in Australia, Sharp (1974) suggested:

... it has sometimes been noted that such rediscoveries [of poverty] recur periodically. The clear implication is that the object of discovery has no neutrally independent existence, but has a good deal to do with ethical and social imperatives that find expression through the eye of the observer ... At least initially the emphasis [here] is on why it is being observed and how it comes about that what was previously hidden can be discovered or rediscovered now.

Sharp then posed the question we need to revisit:

... [W]hy should we assume that 'the truth' of the existence of poverty is any less ambiguous than the earlier assumption that it 'was no longer with us'? (Sharp 1974: 194)

In effect Sharp is insisting that if it is legitimate to enquire into the distribution of income and the processes that produce poverty, along with the methods for doing this, it is equally legitimate to enquire into the social processes involved in this research and 'discovery' process and their consequent impact on policy development. Here there are many complex issues arising out of the relationship 
between reality, our knowledge of it and practical interventions like those which take place as policy-makers intervene.

The second and related proposition that goes to the question of the evidence basis of modern welfare policy is suggested when we consider again how what Furedi (2005) calls 'the fear of politics' has successfully invoked the idea that ordinary decent taxpaying Australians have a lot to fear from something called the 'underclass' a large group of 'welfare dependent' spongers. Bessant (1995) recalls the role played by some social scientists, including self-declared progressives in promoting the idea that we should fear welfare beneficiaries, This politics of fear has helped to drive an evolving regime of income support based on stigmatizing categories hyper-surveillance and disciplinary procedures. In that context the most recent phase in the evolution of Australia's experiment in the 'welfare-to-work' legislation that took effect back on 1 July 2006, gives practical expression to the idea we need to fear single mothers, the long-term unemployed or people with disabilities.

There is of course an old provenance to the idea that there are plenty of people out there who are going to take advantage of 'us'. This fear has propelled governments to sweep up single parents, older age unemployed and people with serious disabilities and chronic illnesses, and take them off their current typically more generous benefits (eg., Single Parent Supporting Benefits or Disability Support Pensions) and locate them in the far meaner regime of surveillance and activity testing associated with Newstart Allowance. 
Of course this is not a new policy. It is a policy that has its antecedents in policy processes that began over 20 years ago (Bessant, Watts et al 2006). The waves of Howard government 'welfare reforms' were but one of a series of social security 'reforms' going back to the so-called 'active society' model first spelled out by the OECD Social policy secretariat ca., 1984-6. The Howard government 'reforms' simply built on the work of its ALP predecessors beginning with the trialing of a 'work-forthe-dole' scheme in 1997 followed by another major review process producing the McClure report of 2001 which spelled out the 'new' doctrine of 'mutual obligation'.

Central to that doctrine as it had been central to the welfare reform process stretching back to the mid-1980s was the core belief that what had once been a problem of 'unemployment' had become a 'problem of 'the unemployed'. This policy process has relied on assiduously promoting the US style critique of the core category of 'welfare' which permitted the representation of the problem as the 'problem' of 'welfare dependency'. "Welfare dependency' became the modern way of talking about the persistence of a class historically referred to as 'paupers' and later as the 'undeserving poor'. 'Welfare dependency' creates unsustainable fiscal burdens on hard working taxpayers. According to this narrative 'welfare dependency' led to life in an 'underclass' of loafers, criminals, addicts, and the mentally ill. It is the very expression of anti-social disorder and immorality. This move relied on social science-based representations of unemployed and low income people as different from 'ordinary Australians' and possibly even a threat to our 
economy and certainly to the ethical order that the regime of wage work had for so long served to embody and to secure.

Our point is simply this: There is of course plenty of evidence to show that this portrait is simply mistaken as eg., Peel(2003) argues. The most significant evidence is the empirical survey undertaken by the then-Department of Family and Community Services (DFACS). This was research work done to support the McClure Committee established in 1999 to make recommendations on 'welfare reform' to the Howard government. This research undertaken in 1999-2000 surveyed a large number of income beneficiaries. It was buried in a technical appendix to the Interim Report of the McClure Committee released early in 2000 and was available only on-line.

This substantial body of data on the characteristics of Australian income support beneficiaries showed that in terms of labour market participation or civic engagement 'they' were no different from 'us' ordinary Australians. This evidence, buried in a Technical Appendix to the McClure Interim Report was not allowed to stymie the official view that the essential problem was the problem vested in the character and life style of welfare beneficiaries which sustained the problem of 'welfare dependence'. On this occasion the evidence had to be repressed and prevented form affecting the outcome of the policy process.

In effect on this occasion this use of evidence is properly the other bookend to the case of the evidence alleging Iraq's possession of WMD. In the case of WMD there 
was no possibility of there being evidence for the existence of WMD in Iraq. So in the case for WMD the evidence was invented or as Campbell (2007) allowed it was 'sexed' up. In the case of welfare reform the opposite problem confronting the relevant government was that the evidence generated for the McClure Committee directly contradicted what the government and indeed the McClure committee already knew. It had to be repressed

In effect this juxtaposition of spin and evidence raises in alarming fashion certain problems of 'political practice' and what we might properly call here the 'politics of truth'. One good way of establishing what the problem is begins by establishing what the evidence on evidence tells us.

That on the one hand government agencies found evidence for WMD in Iraq (when there were none) and that on the other hand government agencies repressed evidence that Australian welfare beneficiaries were no different from the broader Australian community, reminds us that policy-making communities are no less immune than the rest of us to believing what we already know to be the case and looking for the evidence to sustain these beliefs or else work to repress evidence that contradicts what we already know to be the case. That this is so reflects at least basic problems.

\section{THE PROBLEM WITH EVIDENCE}

There are two essential problems with evidence, one to do with the nature of reality the other with the thin capacity of evidence to inform what we think, know, believe 
or do.

One goes to the fundamental interplay between what we can call 'reality' and the various modes of knowing it. While various positivists, empiricists and social science methodologists insist there is no problem here, there is no easy way of getting around a number of difficult problems. Most recently courtesy of Anne-Marie Mol (2002) and John Law (2004) have reminded us that speaking as it were ontologically, reality is messy.

In spelling this proposition out a bit more (and lest it be thought that we are about to launch a post-modernist version of the 'there-is-no-reality-out-there' kind) we need to make it plain that that there are definite processes, relationships, physical things and kinds of practices and ways of life that are 'out there' waiting to be to be discovered. Rather the point to be made as John Law (2004: 6) puts it, is the problem that whatever is out there, is not just going to generate technically complications that get in the way of us knowing 'stuff', but that the world out there necessarily exceeds our capacity to know it.

Anne-Marie Mol (2002) provides an exemplary case study of why and how this is so in the case of the very serious disease called atherosclerosis. Atherosclerosis is the extremely common and all too real medical condition that we might understand as a bad case of 'blocked arteries'. It is a disease produced by combinations of factors including bad genes, poor diet, the aging process, too much cholesterol, lack of exercise, diabetes, and hypertension. It can cause pain, disability, organ failure, 
strokes, heart attacks, vascular disease, gangrene and death. Mol (2002) offers an exemplary study of one version of this disease called lower limb atherosclerosis. Her point is simple. The same all too-real disease does not produce the same symptoms in each patient and the variety of diagnostic techniques including ultra-sound, palpation, PET Scans angiograms and autopsies of amputated limbs or the whole and very dead body all demonstrate varying degrees of utility in diagnosing the scale of illness and informing appropriate treatments. In some patients with precisely the same level of arterial blockage there will be excruciating leg pain (or intermittent claudication) while those other patients with the same degree of blockage report no such pain. The variations in the way the disease manifests and the variation in diagnostic capacity are a striking and simple example of the general point: whatever is meant by an 'out-there reality' it does not exist in a singular or coherent way. 'It' ie., reality is inherently or to put it simply it is ontologically messy.

The problem is that for a very long time lots of people I what can loosely be called the European philosophical tradition have presumed to treat reality in a number of ways that add up to a 'metaphysics of presence' and that are not helpful. Law (2004: 24) points to some of the key problematic ontological assumptions -including the premises of 'out-thereness', 'independence', 'anteriority', 'definiteness' and 'singularity'. Law (2004:30) explicates these assumptions simply. Firstly there is the premise that there is a reality and that 'it' is 'out there' beyond us. Secondly reality is assumed to be independent of our actions and especially of our perceptions. Thirdly reality precedes us. Then and more crucially reality is deemed to be constituted out of definite relations and forms such that it only exists in 'this' form 
and not in 'that' form. Perhaps most crucially given these assumptions, the metaphysicians of presence have assumed that reality is the same everywhere or that is common. That is, it is or has a singular and coherent status or character and is the same everywhere because of its out-thereness', 'independence', 'anteriority' and 'definiteness'.

As Law (2004: 31) notes each of these assumptions need to be treated with plenty of nuance and the frequent use of a phrase when determining the extent to which these assumptions are credible with a phrase like 'it all depends'. Law insists the implications of this rethinking the nature of reality imply that we may need to value a much large number of 'research methods'. This is because it matters that we somehow get the relationship between the world and what we do in it in reasonable alignment What we know and the adequacy of what we know is linked to the quite pressing need to act in a world and to do so in ways that benefit or help us live well rather than killing or harming us.

If we shift our focus away from the 'ontological' to the actual; ways we use evidence then we confront another equally alarming problem. For the other no-less fundamental problem is suggested by abundant evidence gathered over the past half century or so by social psychologists and communications researchers, that the authority and value long vested in the idea of evidence-based rational persuasion is strikingly compromised by what we know about 'cognitive dissonance' and 'groupthink'. 
It can be recalled that Leon Festinger (1957) used the idea of 'cognitive dissonance' to name the problem confronting members of a UFO doomsday cult persuaded by its leader (who had received telepathic messages from the Guardians who flew around in UFOs) that the world would end on a certain day and time. When the anticipated cataclysm failed to eventuate, the cult and their leader faced the problem of 'cognitive dissonance'. (Here the general idea of 'cognition'/'cognitive' refers to a number of things including evidentiary knowledge, attitude, feelings, belief, self-identity and behavior: any or all of these elements can come into conflict). As Festinger suggested the cult members faced the issue of what to do when a prophesy fails. He suggested that they had a few options open to them including ignoring the dissonant evidence (ie., the world had not ended) or to add new consonant evidence. (On this occasion cognitive dissonance was resolved when the leader announced that she had received a 'telepathic message' from the Guardians explaining that her cult had done so much good work in preaching the message that God had spared the world).

Since Festinger's original research there has been a lot of research effort put into exploring the very complex ways people select and use evidence-based information to inform their views of the world, to make judgments or to act. Janis' (1984) account of the role played by what he called 'groupthink' in six major American foreign policy catastrophes merely anticipates and indeed may go some way to explain current catastrophes like the invasion of Iraq. As Janis shows in some detail groups charged with policy making routinely ignore evidence that does not confirm what they already know or want to do an use group processes to silence critics. 
The crucial insight from what is now a very large body of evidence is that the relationship of evidence, emotions and our being in the world is less likely to promote a regard for evidence based-knowledge and activity. It is far morel likely to give us cause to avoid information because it distresses us, or because it increases our anxiety or else is simply unacceptable because it contradicts what we already know, believe or prefer. Alternatively we simply select the evidence that supports our existing views and press on doing what we want to do

Writers like Janis (1953) through to Damasio (2007) have done much to subvert the rationalist premise that humans rely only on rational cognitive processes when they form beliefs, make judgments or act. There is evidence that one of the most important factors that guide people to accept statements as true is the source of the idea: it seems that most us prefer to trust information that comes directly from other people (eg., Johnson 1997; Rintal \& Real 2003). Then as Maslow (1963: 111) suggested, we seem to be trapped between 'a need to know and a fear of knowing'. Evidence from the study of public health campaigns designed to get people to change their behaviour (like anti-skin cancer or 'quit smoking' campaigns) suggest that evidence-based marketing campaigns produce complex reactions and are as likely to lead to avoidance of the evidence as to any desired change in behaviour (O’Keefe 1990). That is, the evidence suggest that more of us are more likely to seek out evidence that helps reduce uncertainty or to accept untrue statements that support what we already believe rather than accept or seek out evidence that is accurate or true but that controverts something we know already or that may 
induce anxiety or stress (Kulthau 1993). Finally there is abundant research evidence which suggests that people screen out evidence or arguments with which they disagree and/or screen in evidence and arguments with which they agree or else use their preferences for one political candidate to accept as true evidence or political marketing material which support a candidate (lyengar et al 2008).

Much about this body of research resists easy compression or generalisation but it does seem to suggest inter alia that 'evidence' largely works in one way ie., it works to reinforce views, theories, self perceptions and beliefs already held, while any strongly dissonant evidence is either rejected or else simply further entrenches views/beliefs facts already believed to be true.

\section{THINKING, JUDGING AND ACTING POLITICALLY: HEIDEGGER}

Though it may seem a bit of a stretch to link this highly empiricist and quantitative tradition of research with the often esoteric and 'difficult' tradition of theory associated with Heidegger (1962) there are at least two fundamental points of contact between the evidence against evidence and the work of Heidegger. On the one hand Heidgegger's often forbiddingly abstract account of our being in the world, and the work of later generations of theorists of practice opens up large questions about the complex ways we live in think, judge and act in the world. Heidegger is important because of his commitment to thinking against the preoccupation with methodology and foundationalist models of scientism which have provided one dominant motif in modern philosophy and the social sciences. The second is his 
account of how we come to form our understanding of the world in the context of our being (Sein) in the world (Dasein) and in the context of our habits and forms of practice into which we are largely unconsciously habituated.

If Heidegger is rightly acknowledged as perhaps the single most influential philosopher of the twentieth century as Guignon (2006: 1-2), for example suggests, then we need to be able to say why this is the case. Recalling that Heidegger's influence is evident in the work of such varied figures for example as Sartre, Gadamer, Arendt, Geertz, Rorty, Taylor, T.S. Kuhn, Foucault, Manent, Latour and Bourdieu points to certain key propositions with which they started and which Heidegger provided.

At the risk of over-simplifying matters -but in the interests of a needful compression what has been called the 'hermeneutic turn' begins with Heidegger's rejection of what Frede (2006: 42) calls 'substance ontology'. That is Heidegger calls out a longstanding premise which links the earliest of philosophers like Plato through to classical physicists, namely the idea that there is an underlying and enduring 'presence': this is as Guignon (2006; 4) points out, what links Plato's Forms, Aristotle's 'primary substances', Descartes' res extensa, Kant's noumena or Newton's grounding his physics in objective time, space and gravity into a persistent 'metaphysics of presence'. However it also generates a series of puzzling binaries which philosophers have endlessly and fruitlessly tried to resolve through debate: at stake are the merits of mind/matter, idealism/realism, facts/values or objectivism/subjectivism. Heidegger undercut this tradition by focusing on 'being' 
(Sein) and in particular on the way humans actually live out their Dasein or 'being there' ie., the ways we live our lives in specific historical life-worlds a state of being. Our being there comes before our will to theorize and abstract starts to take us away from that state of being, Heidegger's 'new' ontology focused instead on the very conditions of intelligibility or understanding whereby we come to be in the world and do so by engaging in constant, intelligible pre-theoretical practice beginning with our use of language.

Heidegger's project began with his recalling the ways we live in the midst of our practical day-to-day activities before we have learned to split mind and matter. This involves him in rejecting any idea of achieving or finding a pure or neutral point of view form which we can gaze in on ourselves by adopting what Manent has called the spectator view advocated by successive realists, naturalist and positivists. Rather Heidegger insists that we start with our own 'life-world' and the ways this 'embeddedness' in a world of practice enables us to engage intelligibly in the world. Hence Heidegger's famous interest in mundane practices like turning a doorknob or hammering away in a workshop. This it should be noted in no way sanctions a retreat into any kind of complacent common sense: rather Heidegger insists on the need to interrogate the fundamentally tragic unfolding of our lives between the moments of our birth and death: Our being in time adds an uncomfortable indeterminacy since as Heidegger puts it 'My being -who I am - is nothing other than what unfolds in the course of my life'. Our agency is constantly at stake as we seek to understand a life which is lived forwards but only on the basis of understanding backwards even as we live forwards: this is a life lived on the edge of 
an 'abyss' (or Abgrund ie., an absence of ground). There is no way out of this 'hermeneutic circle' and certainly methodological escape hatch. Philosophers may have dreamed of finding a secure vantage point from which to get at reality 'as it really is' but there is no escaping the 'hermeneutic circle' The search for constants, regularities and predictive certainties is a chimera undone by our radical 'situatedness' in time - which for all of us eventually runs out. As Guignon (2006: 11) puts it:

... though our general sense of things depend on what we encounter in the world, we can first discover something as significant ... only because we have soaked up a 'preontological understanding' of how things in general can count, through being initiated into the practices and language of our culture.

In short the 'hermeneutic turn' involves the rejection of abstracted (natural) scientific rationality as the only or best source of cognitive and evaluative authority. It also sanctions a resolute rejection of an undue preoccupation with epistemological questions and certain abstracted theoretical criteria for determining what is 'rational'. It begins with the idea that what we know and do is grounded in and made possible by our entry into an historical community of practice -beginning with our immersion in a pre-given linguistic and conceptual worldview or field of discourse. As Gadamer (1994) who deepened Heidegger's account in useful ways argued insisted we confront a diversity of ways of knowing, grounded in what he called our historical nature including certain fundamental intellectual or disciplinary prejudices or what Gerald Holton (1984) called themata which are at work in all the variety of modes of human cognition and practice from art and poetry to physics and 
mathematics. An important entailment of this framework is the proposition that whatever gets to be selected or counted as evidence depends on these themata.

Hopefully enough has been said here about the ontology of being (and mindful of the notoriously abstracted and 'difficult' language Heidegger invented to talk about this), we can see what is at stake here for any account of politics and policy-making. The evidence on evidence suggests that evidence works in two ways: either to persuade people of what they already know/believe to be the case or else to persuade them that they evidence presented to them which contradicts what they already /know believe must be rejected and or confirms them they are already possessed of a true belief or accurate knowledge. Heidegger's 'hermeneutic turn' points to the power of our life world and the habits and practices that dispose us to think, act and feel in certain ways. Yet we are still faced with basic questions and problems that link what we know and think to what we do. How do we do this? One of the essential points of linkage here is the obvious fit between a conception of reality as inherently messy (Law 2004) outlined above, a conception of the value however limited it may be of applied research and the need to live and make do in an inherently messy world filled with a plurality of ethical ideas, and practices and ways of knowing. At stake here is the practical and ethical problem of how to link theory/knowledge and politics/policy. One way forward has been suggested by Arendt (2005) and Flyvbjerg (2004) who have argued for good judgment -or phronesis. 
The recovery of an interest in phronesis a concept developed by Aristotle, has been underway since the recovery of virtue ethics in the 1970s (eg., Anscombe 1968; Maclntyre 1986) and as Arendt (2005) absorbed it into her theory of the political and as it has been promoted subsequently by Nussbaum (1986) and Flyvbjerg (2004) as a framework for contemporary policy and professional practice.

Aristotle (1975) understood phronesis as a basic human virtue (ie., as something we can aim at being excellent at). The idea of good judgment (phronesis) Aristotle understood as a particular kind of practical intellectual virtue: that is, knowing how to act in specific situations. As such it is something we can be socialised or trained in, just as we can practice it and get better at it. Good judgment relies on practice, for as Damasio (2006, xix) observes, it:

...depends on how well we have reasoned in the past; on how well we have classified the events of our past experiences in relation to the emotions that preceded and followed them; and also on how well we have reflected on the successes and failure of our past intuitions. '

Good judgment involves an orientation or disposition to act truthfully and with reason in the practice of deliberation and is oriented to practical action in which some conception of the good is at stake. It is best understood by reference to Aristotle's (1975: 1139a; pp. 27-8; 1178b pp. 20-22) threefold distinction between ways of being or acting in the world. Firstly there is theoresis (involving profound concentrated contemplation a little akin to meditation); then there is poiesis (involving production or world making) and finally there is praxis or social action 
Each of these ways of being and acting in the world is linked to a kind of knowledge there is episteme theoretike (or theoretical knowledge achieved by various styles of valid reasoning); there is techne (or technical skill) involving a trained capacity for action and finally there is phronesis or practical wisdom. Each of these are different yet complementary capacities and ways of knowing and being in the world.

Translated into present-day language good judgment refers to a practical wisdom that is more than simply knowing about principles of action. Good judgment refers to a practitioner having the wisdom that come though experience to make good judgment and to know how and when to act in ways that will promote the basic goods. Good judgment refers to an ability on the part of the practitioner to know when and in what ways to act courageously, honestly, or generously. It refers to the ability to know how and why what might be an act of courage in one context is high risk or reckless in another. This means being both context sensitive and able to judge what the right measure of an action is. (Arostotle spoke often about a golden mean" think of a virtue like 'courage'. Too little is the vice of 'cowardice' too much is the vice of foolhardiness.

To speak about the pursuit of goods reinstates a proper regard for knowledge. To say how we may think about good judgement entails accepting first that knowledge is a fundamental and universal human good. John Finnis (1980) provides one of the most compelling modern accounts of the nature of knowledge as a good using a kind of analytic dialectic which moves backwards and forwards between assessments of human good and its practical requirements and explanatory descriptions using historical, experimental, and sociological materials and methods. This good he 
(1980: 60) says, is grounded in a very common human activity, namely the 'activity of trying to find out, to understand and to judge matters correctly'. As he (1980: 61) puts it:

Commonly one's interest in knowledge, in getting to the truth of the matter, is not bounded by the particular questions that first aroused one's desire to find out ... In explaining, to oneself and others, what one is up to, one finds oneself able and ready to refer to finding out, knowledge, truth as sufficient explanations of the point of one's activity, project or commitment. One finds oneself reflecting that ignorance and muddle are to be avoided ... 'it's good to find out...' now seems to be applicable not merely in relation to oneself ... but at large ... and for anyone.

Finnis (1980: 65) proposes that knowledge is a human good and there are no sufficient reasons for doubting that this is the case. He allows that the truth of this claim 'cannot be demonstrated, but then it needs no demonstration'. It is simply self-evident. Or rather as Finnis (1980: 74-5) proceeds to suggest, any scepticism about the basic value of knowledge is self-defeating or self-nullifying.

The second basic idea is that phronesis is a deeply practical capacity. Those who work in this tradition stress the need to be good at practical deliberation addressing the question 'what ought I do in this case?' This question necessarily arises in the contexts of our daily lives with other people. An orientation to phronesis suggests that addressing and answering ethical questions has less to do with philosophical analysis and much more to do with being a good person who can in each circumstance try to exercise good judgment. 
It is against this backdrop that Arendt's relentless attempt to specify what it is that marks out politics as our highest accomplishment and the challenge it daily poses to think well and to do well takes its salience. The need to do so arises in Arendt's mind (2005: 93-5) from the fact of difference between us ie., the fact of human plurality This means for her that there is no human essence and no essence of politics: politics is what arises between men. On the one hand she notes the inevitability of prejudices which constitute our life world

The prejudices that we share, that we take to be self evident, that we toss out in conversation are... political in the broadest sense of the word, that is, something that constitutes an integral part of those human affairs that are the context in which we go about our daily lives. That prejudices play such a large role in daily life and therefore in politics is not something that we should bemoan as such, or for that matter attempt to change ... men cannot live without prejudices...(Arendt 205: 99)

(As she notes to attempt to overcome all our prejudices would require 'a superhuman alertness') Equally the task of politics involves distinguishing between genuine prejudices and acknowledging the requirements of good judgment: our substitution of prejudice for judgment becomes dangerous only if it spreads into the political realm where we cannot function at all without judgement(2005:101). The practice of judgment relies in her luminous phrase on developing both our capacity and will 'to think what we do'. 
Arendt's phenomenology of thinking reveals its relentlessly dissolvent qualities. Her famous account of Adolph Eichmann (Arendt 1963) suggested not that there is an Eichmann in each of us, but rather that there is a general atrophy of our powers of judgement, an inability to think without rules. Thinking entails a capacity to judge moral and political matters and then to take appropriate action. This inability to judge is associated with an increasing reliance on ready-to-hand principles and organisational practices that seek to enable us to navigate everyday life without having to stop and think. That is, we adopt an automatic pilot view of what we need to think or do ie., an everyday thoughtlessness. The faculty of judgement the ability to tell right from wrong is dependent on the ability to think well. As Arendt (2005) and Vlastos (1992) remind us this is the value of Socrates. Socrates show us how to think representing the ability to make public in discourse the thinking process - the dialogue that soundlessly goes on within me between me and myself. Thinking produces uncertainty and in this way thinking inevitably has an undermining effect on all established criteria, values principles and unthinking customs and prejudices.

\section{CONCLUSION}

The implication of this discussion for a consideration of the current enthusiasm for evidence-based policy is simple. Thinking well trumps evidence: the practice of good judgment comes prior to the mindless conviction that anything can be measured. While evidence based policy may be a boon to any number of university-based 
researchers we need to exercise a duty of care to think about the effect of this not least of all on universities.

In a spirit of provocation we think Susan Haack (1999) is right to point to the prevalence of several unacceptable kinds of research. Like Haack we assume that there are major problems when we tolerate sham research and fake research. If we have a proper regard for the value of good public scholarship we will not readily tolerate the defence of sham research or fake research by appealing to notions of academic freedom.

Though this is a proposition itself requiring inquiry to render persuasive, we think too much of what currently passes for university based research is either 'sham inquiry' or 'fake inquiry' (See Haack 1999: 189-92).

Sham inquiry tries to make a case for the truth of a proposition which is evidence and argument-proof. The sham inquirer is not primarily concerned to find out how things really are but to make a case for some immovably held preconceived belief. 'Fake inquiry' on the other hand tries to make a case for the truth of some proposition advancing which s/he believes will benefit him or herself, but to the truth value of which $s /$ he is indifferent.

The corrosive effect of insisting on gathering and using evidence to evaluate the effectiveness of universities eg., by measuring research quality has been well represented by Susan Haack. A genuine inquirer, says Haack (1999: 190): 
$\ldots$ is motivated to get to the truth of the matter that concerns him, he is motivated to seek out and assess the worth of evidence and arguments thoroughly... it is a matter of willingness to rethink, to reappraise, to spend as long as it takes on the picky detail that might just be fatal, to give as much thought to the final one percent as to the rest.

This is why as she goes on to say it matters that that the space in which inquiry is carried out supports and rewards real inquiry. Her checklist of the things that mark out such an environment speaks to the current capacity of universities to support genuine inquiry. She (1999: 194) tells of a recent request for a reference for a junior colleague in a British university:

Though the job was described as a lectureship it was made very clear that teaching ability wasn't important, that the main qualification for the position was that the person appointed should publish a sufficient number of papers in sufficiently prestigious journals as to raise the department's standing in the governments 'research ranking'...

This is what Jacques Barzun called 'preposterism'. 'Preposterism' is the practice which

... puts the last first and the first last e.g., Valuing knowledge we preposterize the idea and say ... everybody shall produce written research in order to live and it shall be decreed a knowledge explosion

As Haack (1999: 194) insists adapting to a culture of grants-and-research projects has:

...tended to lower the motive with which [research] work is done: it has fostered an environment hospitable to sham and fake inquiry. The culture of 
grants-and-research projects and the conception of productivity and efficiency that culture fosters discourage candid acknowledgment that you may work for years at what turns out to be a dead end and constitute standing encouragement to exaggeration, half truth and outright dishonesty about what you have achieved. ... Inevitably intellectual honesty is eroded.

That is why preserving the capacity of language to tell the truth and to practice politics requires that engage in this practice of judgment and thinking well ourselves. Let us suppose then that there ought to be a close link between politics good judgment and truth telling. As Don Watson (2002:48) has insisted we live now in a political community that has cut the basic thread of truth and trust. In his great essay, 'Politics and the English language', George Orwell thought about the political role played by language in establishing the fundamental conditions of trust and truth. Orwell held that truth in language use established the very conditions of trust and understanding between people, qualities fundamental to the quality of people's lives and relationships and to the 'health' of any civil society (See Shapin 1996 for an elucidation of the etymological links between 'truth' and 'trust').

Orwell argued that language should function so as 'not to anaesthetize a portion of one's brain' but that it should carry the capacity to perform or express our capacity for clear thinking. 'To think clearly is to a necessary first step towards political regeneration'. Equally he showed how a lack of regard for truth in language permitted everything from petty tyrannies to the political catastrophes unleashed by totalitarian political formations. Upon this basis it is possible to envisage a language practice which keeps intact, in Don Watsons' (2002:48) words, 'the threads of a 
common sensibility which join the people to their representatives and institutions'.

This formulation speaks precisely to the current state of our public culture, its

instiutions and to the activities we should expect of our politicians and policy-makers

no less than our teachers, writers, scientists and artists.

\section{REFERENCES}

ABS, 2010, A Guide for Using Statistics for Evidence based policy, ABS Cat. No. 1500.0, Canberra. Agamben, G., 2005, States of Exception (Trans. K. Attell), University of Chicago Press, Chicago. Agamben, G., Homo Sacer: Sovereign Power and Bare Life, University of Chicago Press, Chicago. Arendt, H., 1958, The Human Condition, Harcourt Brace and Jovanovich, New York.

Arendt, H., 1968, 'Truth and Politics', in Between Past and Future, Harcourt Brace and Jovanovich, New York.

Arendt, H., 1975, The Life of the Mind, Harcourt Brace and Jovanovich, New York.

Arendt, H., 2005, The Promise of Politics, (ed J., Kohn), Schocken, New York

Argyrous, G., 2009, 'Evidence for policy and decision-Making: A Practical Guide', Public Organisation Review, vol.10 (2), 191-4.

Aristotle, 1975, Ethica Nichomachea, (Vol IX), The Works of Aristotle, Oxford University Press, Oxford,

Australian Institute of Family Studies, 2002, Introducing the Longitudinal Study of Australian Children, [Online], Available: http://www.aifs.gov.au/lsac/pubs.html [2002, May 16].

Australian Public Service Commission, 2007, Tackling Wicked Problems A Public policy perspective, APSC, Canberra

Ballard, J.G,. 2007, Kingdom Come, Fourth Estate, London.

Banks, G., 2009, Challenges of Evidence-based Policy making, Commonwealth of Australia, Canberra.

Banks, G., 2009, Evidence based policy making: What is it? How do we get it? Productivity Commission ANU Public Lecture Series, ANZSOG, Canberra February

Beresford, Q., 1998, Selling democracy short: Elections in the age of the market. Current Affairs Bulletin, Vol. 74, No. 5, pp. 24-32.

Bernays E., 1928, Propoganda, Horace Liverwright, New York.

Bessant, J., 1995, 'The Discovery of a Juvenile 'Underclass', ANZJS, vol36, (2) 55-72

Bessant, J., Watts, R., Dalton, T., \& Smyth, P., 2006, Talking Policy: How Social Policy is Made. Allen \& Unwin, Sydney.

Bevir, M., and Rhodes, R., 2003, Interpreting British Government, Routledge London. Blair,T., 1997, Labour Party Manifesto for the 1997 General Election,

Bishop R., 2007. The Philosophy of the Social Sciences, Continuum, New York.

Bloor, D., 1991, Knowledge and Social Imagery, The University of Chicago Press, Chicago

Bourdieu, P., 2008, Political Interventions: Social science and Political Action, Verso, London.

Brown, W., 2010, Walled States, Waning Sovereignty Zone Books, Cam bridge.

Cabinet Office, 1999a, Modernising Government White Paper, Cm 4310, Cabinet Office, London,

Cabinet Office, 1999b, Professional Policy Making for the Twenty first century: A report by the Strategic Policy Management Team, Cabinet Office, London.

Calhoun, C., 1992, (ed), Habermas and the Public Sphere, MIT Press, Cambridge,

Campbell, A., 2007, The Campbell Diaries, Random House, London.

Cappella, J. N. and Jamieson, K. 1997, Spiral of Cynicism: The Press and the Public Good, Oxford University Press, New York.

Cartwright, N., 2009, 'Evidence -based policy: What's to be done about relevance? 
Centrelink 2002, Centrelink's 2002-2005 Business Plan, [Online], Available: http: www.centrelink.gov.au/internet/internet.nsf/filestores/pr108_0207/\$file/pr1008_0207en.pdf [2002, Jan. 17]

Certeau, M. de 1988 The Practice of Everyday Life, UCLA Press, Berkeley.

Coalition for Evidence Based Policy 2000, Mission and Agenda, [Online], Available: www.exelgov.org/performance/evidence/execsumm.htm

Cook, F. 2001, Evidence-based policy making in a democracy: exploring the role of policy research in conjunction with politics and public opinion, paper prepared for delivery at the 2001 Annual meeting of the American Political Science Association, San Francisco, August 30-September, 2, 2001.

Damasion, A., 2007, Descartes' Error, $\left(2^{\text {nd }}\right.$ ed) Grosset-Putnam, New York.

Daston, L., \& Gallison, P., 2008, Objectivity, Zone Books, Brooklyn.

Davies, H., Nutley, S., \& Smith, P., 2000, What Works? Evidence-based Policy and Practice in Public services, Policy Press, Bristol.

Davies, P., 2012, 'The State of Evidence-based Policy Evaluation and its role i Policy formation', Journal of the National institute of Economic and Social Research, vol. 219: 41-52

Dean, M., 191, The Constitution of Poverty, Routledge, London.

Deutsch, D., 2012, The Beginning of Infinity, Riverview, New York.

Drogin, B., 2007, Curveball: Spies, Lies and the Con Man who Caused a War, Harper, New York.

Edwards, M., 2001, Social policy, Public Policy: From Problem to Practice, Allen \& Unwin, Sydney.

Ellul, J., 1965, Propaganda: The formation of Men's Attitudes, Vintage New York.

Elster, J., 2007, Explaining Social behaviour: More nuts and bolts for the Social Sciences, Cambridge university Press, Cambridge. Evans, M., 2007, 'The Art of Prescription: Theory and practice in Public administration research', Public Policy and Administration, 22 (1) 128-52.

Evidence Network 2002, The History of Evidence Network, [Online] Available: http://www.evidencenetwork.org/history.asp [Dec. 6, 2002].

Festinger, L., 1957, A Theory of Cognitive dissonance, Stanford University Press, Stanford.

Finlayson, A., 2004, 'Meaning and politics: Assessing Bevir and Rhodes;, in British Journal of Politics and International relations, vol.6 (2) 149-56

Finnis, J. 1980, Natural Law and Natural Rights, Oxford University Press, Clarendon.

Fischer, F., 1998. 'Beyond Empiricism: Policy inquiry in Postpositivist Perspective', in Policy Studies Journal, vol 26. (1): 129-46

Flyvbjerg B., 2004, Making Social Science Matter, Cambridge University Press, Cambridge.

Foucault, M., 1991, 'Governmentality' in Graham Burchell, Colin Gordon, and Peter Miller, (eds)The Foucault effect: Studies in Governmentality, University of Chicago Press, Chicago.

Frankfurt, H., 2005, On Bullshit, Princeton University Press, Princeton.

Franklin, B. 1994, Packaging Politics: Political Communications in Britain's Media Democracy, Edward Arnold, London.

Frede, D., 2006, 'The Question of being: Heidegger's project, in . Guignon. C. 2006 (ed.), The Cambridge Companion to Heidegger ( $2^{\text {nd }}$ ed) Cambridge University Press, Cambridge

Furedi, F., 2005, Politics of Fear: Beyond Left and Right, Continuum, London.

Garnham, N., 1992, The media and the public sphere. In C. Calhoun (Ed.).

Glasby, J., Walshe K., \& Harvey, G., 2007, What Counts as evidence in Evidence Based practice?, Evidence and Policy, Vol 3 (3) 325-27

Grattan, M., 1997,' The politics of spin', Australian Studies in Journalism, vol. 7: 1998: 32-45

Grayling, A.C. 2003, What is Good? The Search for the best Way to Live, Weidenfeld \& Nicholson, London.

Graysion, L. 2007, Policy makers use evidence Only when it Suits them: Discuss, Center for Evidence Based Policy and Practice, London.

Greenberg, K., \& Lewis, A., 2005, (eds), The Torture Papers: The Road to Abu Ghraib, Cambridge University Press, Cambridge.

Guignon. C. 2006 (ed.), The Cambridge Companion to Heidegger ( $2^{\text {nd }}$ ed) Cambridge University Press, Cambridge

Haack, S., 1998, Manifesto of a Passionate Moderate: Unfashionable Essays, University of Chicago Press, Chicago.

Haack, S., 2007, Defending Science -Within Reason, Prometheus Books, Amherst.

Hacking, I., 2004, Historical Ontology, Harvard Univerrsity Press, Cambridge. 
Hansen, P., 1993, Hannah Arendt: Politics, History and Citizenship, Stanford University Press, Stanford. Harris, P. and Wring, D. 2002, Political Marketing, London, Butterworth-

Harris, P., Moss, D and Vetter, N. 1999, Machiavelli and Public Affairs: A

Hay, C., 2002, Political Analysis: A critical introduction, Palgrave, Macmillan.

Head, B., 2008, 'Three lenses of Evidence-based policy', Australian Journal of Public Administration, vol 67 (1) 1-11.

Head, B., 2009, 'Evidence based policy: Principles and requirements', in Productivity Commission, Strengthening Evidence based policy in the Australian Federation : Roundtable Proceedings, Canberra 17-18 August, Vol 1: 13-26

Heidegger, M., 1962, Being and Time (Trans J. Macquarrie \& E. Robinson),SCM Press, San Francisco,

Herman, E.S., and Chomsky,N., 1988, Manufacturing Consent, Pantheon, New York.

Hirschman, A.O. 1997, The Passions and the Interests, Princeton University Press, Princeton.

Ignatieff, M., (ed)., 2006, American Exceptionalism and Human Rights, Princeton University Press, Princeton.

Iyengar, S., Hahn,K., Krosnick, J., \& Walker, J., 2008, 'Selective Exposure to campaign Communication: The role of anticipated Agreement and Issue Public membership', The Journal of Politics, vol 70, (1) pp186-200

Janis, I., 1953, 'Effects of Fear Arousing Communications', Journal of Abnormal Psychology, vol 48, pp 78-92

Johnson, J., 1997, Cancer related Information Seeking, Hampton Press, Cresskill.

Jones, N. 1995, Soundbites and Spin Doctors: How Politicians Manipulate Citizens Indigo London.

Jones, N., 1997, Campaign 1997: How the General Election was Won and Lost, Indigo, London.

Kosseleck, R., 2002, The Practice of Conceptual History: Timing History, Spacing concepts (Trans T. Presner et al), Stanford University Press, Stanford .

Kulthau, C., 1993, 'A Principle of Uncertainty for Information seeking', Journal of Documentation, vol 49, (2), pp 339-55.

Kurtz, 1998, Spin Cycle: Inside the Clinton Propaganda Machine, The Free Press, New York.

Latham, M. 2001, 'Myths of the Welfare State', Policy, Vol 17, no 3, pp. 40-43.

Law, J., 2004, After Method: Mess in Social Science Research, Routledge, Abingdon.

Lemert, C., 1995, Sociology after the Crisis, Westview Press, Boulder.

Leon, de p., \& Weibel C., 2010, 'Policy process research for democracy: a commentary on Lasswell's vision' International Journal of Policy Studies, Volume 1, Number 2, December

Lindblom, C., 1990, Inquiry and Change, Yale University Press, New Haven.

Lippmann, W., 1932, Public Opinion Allen\&Unwin, London

Marr, D., \& Wilkinson, M., 2006 Dark Victory, (2 ${ }^{\text {nd }}$ ed.) Allen \& Unwin, Sydney

Martens, P., and Roos, N., 2005, 'When health services Researchers and policy makers interact: tales from the tectonic plates', Healthcare Policy, vol 1 (10 72-84.

Maslow, A., 1963, 'The Need to Know and the Fear of Knowing', Journal of General Psychology vol 68 : $p$ p111-25

Mayer, H., 1994, Mayer on the Media: Issues and Arguments, Tiffin, R., (ed), Allen \& Unwin, St. Leonards.

Mol, Anne-Marie, 2003, The Body Multiple: Ontology in Medical Practice, Duke University Press, Durham.

Moore, N., 2007, The Origins of Modern Spin, Palgrave, London

Mulgan, G., 2005 'Government, Knowledge and the Business of Policy Making: the Potential and Limits of Evidence-Based Policy', Evidence and Policy, vol.1, (2) 215-226

National Health and Medical Research Council (2003) Practitioner Fellowships, [Online], Available: www.health.gov.au/nhmrc/research/train/practfly.htm [2003, Jan. 16]

Nussbaum, M., 1986, The Fragility of Goodness, Cambridge University Press, Cambridge.

Nutley, S. Davies, H. \& Walter, I. 2002, Evidence Based Policy and Practice: Cross Sector Lessons from the UK, Keynote paper for the Social Policy Research and Evaluation Conference, Wellington, New Zealand, 2-3 July.

Nutley, S., 2003, 'Bridging the policy/Research divide', Facing the Future Conference, National Institute of Governance Conference, Canberra 23-24 april

O'Connor, A., 2000, Poverty Knowledge, Princeton university Press, Princeton.

O'Dwyer, L., 2004, A Critical Review of Evidence Based policy, AHURI Final Report No. 58, May AHURI Southern Research Center, Melbourne 
O'Keefe, D., 1990, Persuasion Theory and Research, Sage Newbury Park

Oakley, A., 2000, Experiments in Knowing, Polity Press, Cambridge.

Oancea A., \& Furlong, J., 2007, 'Expressions of Excellence and the Assessment of Applied and Practice based Research', Research Papers in Education, vol.22 (2) pp. 119-37

Orwell, G., 1946, 'Politics and the English language', in Shooting the Elephant and Other essays, Secker \& Warburg, London

Parsons, W. 2001, Modernising Policy-making for the Twenty First Century: The Professional Model, in Public Policy and Administration, vol. 16, no 3, pp. 93-110.

Parsons, W., 2002, 'From Muddling through to Muddling up: evidence based policy and the modernisation of British government', Public Policy Administration vol 17 (3) 43-60

Pearson, M., and Mclean, H., 2010, "Quantifying government media relations in Queensland "Public communication review, 1 (2), 18-32.

Pearson, M., \& Patching, R., 2008, Government media relations: A Spin through the Literatur',

Humanities \& Social Sciences papers. Paper 228.http://epublications.bond.edu.au/hss_pubs/228

Peel, M., 2003, The Lowest Rung, Cambridge University Press, Cambridge.

Perri, S. (2002) 'Can Policy Making be Evidence Based?' MCC Building knowledge for integrated care, vol 10, no 1, pp. 3-9.

Pielke, R., 2007, The Honest broker: making sense of science in policy and politics, Cambridge University Press, New York

Popper, K., 2002, Conjectures and Refutations, Routledge, London.

Productivity Commission, 2009, Strengthening Evidence based policy in the Australian Federation: Roundtable Proceedings, Canberra 17-18 August, (2 Vols)

Public Policy Institute, 2011, 'Wicked problems: Do they exist?' Policy Update Issue 223 March

Putnam, H., 2005, The Fact Value dichotomy and other Essays, Harvard University Press, Cambridge.

Quine, W., 1974, 'On Popper's Negative Methodology', in Paul A. Schilpp (ed.), The Philosophy of Karl Popper, The Library of Living Philosophers; Open Court Publishing, La Salle.

Rampton, S., \& Stauber, J., 2003, Weapons of Mass Deception, Hodder London.

Reid, F., 2003, 'Evidence Based policy -Where is the evidence for it?' Working Paper 3, School for Policy Studies, University of Bristol.

Reynolds, S. 2000, 'The Anatomy of Evidence-Based Practice: Principles and Methods', in EvidenceBased Practice: A Critical Appraisal, (eds) L. Trinder \& S. Reynolds, Blackwell Science, Oxford.

Rintal, R., \& Real, K., 2003, 'Perceived Risk and Efficacy Beliefs as Motivators of Change: Use of the Risk Perception Attitude (RPA) Framework to Understand Health Behaviour', Human Communications Research, Vol 29 (3) pp. 370-99.

Rose, J., 1996, States of Fantasy, Oxford University Press, Oxford.

Rose, N. 1999, Powers of Freedom: Reframing Political Thought, Cambridge University Press: Cambridge.

Rose, N., 1996, 'The death of the Social: Refiguring the territory of Government, Economy and Society, vol.25. (3)

Rosenstock, L. and Lee, J. 2002, 'Attacks on science: The risks to evidence-based policy', American Journal of Public Health, vol 92, Issue 1, pp. 14-18.

Rudd, K. 2008, Prime Minister: Address to Heads of Agencies and Members of Senior Executive Service, 30 April, http://www.pm.gov.au/node/5817

Sanderson, I. 2002, Making Sense of 'What Works': Evidence-Based Policy Making as Instrumental Rationality? Paper presented at the Political Studies Association Annual Conference Aberdeen, 5th- 7th 2002.

Schon, D., 1999, Frame Reflection: Towards the resolution of Intractable policy Controversies, Basic Books, New York.

Shapin, S., 1996, A Social history of Truth, University of Chicago Press, Chicago.

Sharp, G., 1974, 'Interpretations of Poverty', ANZJS, vol.10, no.3 pp. 194-199.

Socialism Today, 2003 Editorial: 'Spin or the Art of Lying', Issue 77, September, http://www.socialismtoday.org/77/hutton.html 
Solesbury, W. 2001, Evidence Based Policy Whence it Came and Where it's Going, ESRC UK Centre for Evidence Based Policy and Practice: Working Paper 1, ESRCF UK Centre for Evidence Based Policy and Practice, London.

Stockwell, S., 2007, 'The Spin Doctors: Government media Advisers' In S. Young (Ed.).

Tallis, R., 2011, Aping Mankind; Neuromania, Darwinitis and the Misrepresentation of Humanity, Acumen, London,

The Campbell Collaboration 2003, About the Campbell Collaboration, [Online], Available: http://www.campbellcollaboration.org/FraAbout.html [2003, Jan. 14]

The Cochrane Collaboration 2003, Brochure, [Online\}, Available: http://www.cochrane.org/cochrane/cc-broch.htm [2003, Jan. 13]

Tilley, N. \& Laycock, G. 2000, Joining up Research, Policy and Practice about Crime, Policy Studies, vol 21, no 3, pp. 213-227.

Trinder, L. 2000, 'Introduction: the context of evidence-based practice', in Evidence-Based Practice: A Critical Appraisal, eds L. Trinder \& S. Reynolds, Blackwell Science, Oxford.

Trinder, L. and Reynolds, S. (eds) 2000, Evidence-Based Practice: A Critical Appraisal, Blackwell Science, Oxford.

United States Coalition for Evidence Based Policy 2002, Program Description, [Online], Available: http://www.excelgov.org/displayContent.asp?Keyword=prppcProgDesc [Feb, 6, 2002]

van Onselen, P., and Errington, W., 2005, 'The Government Members' Secretariat: The beating heart of Australia's PR state', paper delivered at the ANZCA Conference Christchurch, New Zealand, 4-7 July.

Vlastos, G., 1991, Socrates: Ironist and Moral Philosopher, Cambridge University Press, Cambridge.

Ward, I. 2003, An Australian PR state? Australian Journal of Communication, 30(1), 25-42.

Watson, D., 2002, Recollections of a Bleeding Heart: A Portrait of Paul Keating, Knopf, Sydney.

Wells, P., 2004, 'New Labour and Evidence Based Policy Making', Paper presented to the PERC Research Seminar 16th May 2004 Centre for Regional Economic and Social Research Sheffield Hallam University, Sheffield.

Whitworth, J. 1998, Better Health Outcomes Newsletter, vol 4, no 2 pp. 1-4.

Wikipedia 2012, 'Evidence-based policy', http://en.wikipedia.org/wiki/Evidence-based_policy

Winter, I., \& Seelig, T., 2001, Housing Research, Policy Relevance and a Housing Imagination in Australia, unpublished conference paper, presented at 2001 Housing Studies Association Conference, Cardiff University, September.

Wolin, S., 2008, Democracy Incorporated: Managed Democracy and the Specter of Inverted

Totalitarianism, Princeton University Press, Princeton.

Young, K., Ashby, D., Annette, B., \& Grayson, L., 2002, 'Social Science and the Evidence-based Policy

Movement, Social Policy \& Society, vol 1 no 3, pp. 215-224.

Young, S., 2011, Evidence of democracy? The relationship between evidence-based policy and democratic government', Journal of Public Administration and Policy Research, vol. 3 (1) 19027

Zussman, D., 2003, 'Evidence-based Policy Making: Some Observations of Recent Canadian Experience', Social Policy Journal of New Zealand, Issue 20: 64-71 
POOL

The point is only that a fact, an event can never be witnessed by anyone who may want to know about it, whereas rational or mathematical truth presents itself as self-evident to everyone endowed with the same brain power; its compelling nature is universal, while the compelling force of factual truth is limited; it does not reach those who not having been witnesses, have to rely on the testimony of others, whom one may or may not believe. The true opposite of factual, as distinguished from rational truth is not error or illusion but the deliberate lie.

Hannah Arendt: 1975: 59 